\title{
Differential expression of IgG Fc binding protein (FcyBP) in human normal thyroid tissue, thyroid adenomas and thyroid carcinomas
}

\author{
N O'Donovan ${ }^{1}$, A Fischer ${ }^{2}$, E-M Abdo, F Simon, H J Peter, \\ H Gerber $^{3}$, U Buergi and U Marti ${ }^{3}$ \\ Department of General Internal Medicine, University Hospital, University of Bern, Switzerland \\ ${ }^{1}$ Department of Medical Oncology, St Vincent's University Hospital, Dublin, Ireland \\ ${ }^{2}$ BASF-LYNX Bioscience AG, D-69120 Heidelberg, Germany \\ ${ }^{3}$ Department of Clinical Chemistry, University Hospital, University of Bern, Freiburgstasse 15, CH-3010 Bern, Switzerland \\ (Requests for offprints should be addressed to U Marti; Email: ulrich.marti@dkf2.unibe.ch) \\ ( $\mathrm{N}$ O'Donovan, A Fischer and E-M Abdo contributed equally to this paper)
}

\begin{abstract}
The genetic events involved in thyroid carcinogenesis are still incompletely understood. Several rearrangements and mutations of oncogenes have been implicated in the development of thyroid papillary carcinomas, follicular adenomas and carcinomas. However, none of these molecular alterations is suitable either as a general marker for the diagnosis of thyroid carcinomas or to differentiate between thyroid follicular adenomas and carcinomas. In order to identify new genes with altered expression which could serve as such markers, we analyzed RNA from thyroid tumor and normal tissue using a novel technique called restriction-mediated differential display. Several differentially expressed genes were identified, including the gene for IgG Fc binding protein (Fc $\gamma B P$ ). Differential
\end{abstract}

expression of $\mathrm{Fc} \gamma \mathrm{BP}$ was confirmed by quantitative realtime RT-PCR. Our experiments showed that IgG Fc binding protein $(\mathrm{Fc} \gamma \mathrm{BP})$ is differentially expressed in normal thyroid tissue, thyroid adenomas and thyroid carcinomas. While the Fc $\gamma \mathrm{BP}$ gene is constitutively expressed in normal thyroid tissue, its expression is significantly increased in follicular thyroid adenomas and significantly decreased in papillary and follicular thyroid carcinomas. Thus, measurement of the expression levels of Fc $\gamma \mathrm{BP}$ in thyroid biopsies might help to make the otherwise difficult distinction between a thyroid follicular adenoma and a follicular carcinoma.

Journal of Endocrinology (2002) 174, 517-524

\section{Introduction}

Thyroid tumors are the most frequently occurring endocrine tumors. Thyroid nodules are found in about $4-7 \%$ of the Northern American population on physical examination (Ridgway 1998). Ultrasonographic and autopsy studies reveal an even higher (30-50\%) prevalence of thyroid nodules in adults (Ezzat et al. 1994). Thyroid nodules are particularly frequent in older people. However, less than $10 \%$ of these nodules are malignant (Schlumberger 1998). To decide on the most appropriate therapy, it is therefore important to have means to distinguish between benign and malignant thyroid nodules.

Fine-needle aspiration biopsy cytology is currently the most useful single method for preoperatively distinguishing between benign and malignant thyroid tumors. However, a significant percentage $(10-25 \%)$ of fine-needle aspiration biopsies are non-diagnostic, for example because of inadequate samples or the presence of an indeterminate cytological pattern, referred to as follicular neoplasia
(Russo et al. 1999). Specific molecular markers for thyroid carcinomas would be very useful to improve the proportion of definite diagnoses which can be made from fine-needle aspiration biopsies. To date, several potential markers have been found but none of them is completely satisfactory. The RET oncogene translocation (RET/ PTC), for example, has been identified as a papillary thyroid carcinoma marker. However, it is only expressed in a minority of papillary carcinomas (11-25\%) (Jhiang \& Mazzaferri 1994). Another potential thyroid tumor marker is oncofetal fibronectin. An RT-PCR assay has been developed for detection of oncofetal fibronectin mRNA in fine-needle aspiration biopsies of the thyroid gland with a diagnostic sensitivity and specificity of $96.9 \%$ (Takano et al. 1998), but this is limited by the fact that oncofetal fibronectin is only expressed in papillary thyroid carcinomas. Mutations in the ras family of oncogenes are found in about $50 \%$ of follicular thyroid carcinomas (Lemoine et al. 1989). The most recently identified potential genetic marker for follicular carcinomas is a translocation of the thyroid transcription factor PAX8 (Kroll et al. 2000). 
However, a genetic marker to distinguish accurately all thyroid carcinomas from benign tumors has not yet been identified.

The goal of the present study was to identify new genes which could serve as genetic markers for thyroid cancers. For this purpose we compared mRNA expression in thyroid tissue with nodular hyperplasia, in thyroid adenomas and in carcinomas with mRNA expression in normal tissue from the thyroids containing those pathological alterations. This comparison was carried out using restriction-mediated differential display (RMDD) (Fischer 1995). RMDD combines the power of restriction-based fragment generation for expression analysis with the unsurpassed convenience and resolution of direct-blotting electrophoresis, non-radioactive detection and direct sequencing of candidate bands without cloning steps. During the past few years, several investigators have successfully used cDNA-derived restriction fragments for comparative display of expressed genes (Fischer et al. 1995, Kato 1996, Prashar \& Weissman 1996, Matz et al. 1997). Compared with differential display (DD), such restrictionbased technologies provide significantly higher reproducibility and reliability than protocols based on arbitrary binding of PCR primers (Fischer et al. 1995), as is the case with DD and with the related RNA arbitrary fingerprinting (Welsh et al. 1992). The RMDD protocol, as employed in this study, allows systematic and unbiased coverage of all transcripts present in a sample, above a certain threshold. Spiking experiments with RNA showed a signal up to a dilution of 1:50 000 (authors' unpublished observation).

In preliminary RMDD experiments, several genes that are differentially expressed in normal thyroid tissue and thyroid carcinomas were identified. One of them, the $\operatorname{IgG}$ $\mathrm{Fc}_{\mathrm{c}}$ binding protein $(\mathrm{Fc} \gamma \mathrm{BP})$ gene was chosen for further investigation because its expression has not previously been described in thyroid tissue.

To obtain quantitative information on the expression of Fc $\gamma B$ P we used quantitative real-time RT-PCR analysis on a larger number of thyroid tissue samples. We found that, in comparison with normal thyroid tissue and benign thyroid alterations such as nodular hyperplasia and adenomas, Fc $\gamma B$ P expression was significantly reduced in thyroid (papillary and follicular) carcinomas. Assessment of Fc $\gamma \mathrm{BP}$ gene expression might thus be helpful in distinguishing benign from malignant thyroid alterations, particularly if it could be utilized on material obtained from fine-needle aspiration biopsies.

\section{Materials and Methods}

\section{Tissue samples and cell lines}

Thyroid tissue samples (from 6 papillary carcinomas, 3 follicular carcinomas, 6 adenomas, 3 oxyphilic (Hurthle cell) adenomas, 4 nodular hyperplasias, and normal tissues from the corresponding thyroids) were obtained from patients undergoing thyroid surgery. The age of the patients at the time of surgery was between 16 and 80 years. Tissue specimens were immediately frozen in liquid nitrogen. Histological diagnoses were made by experienced thyroid pathologists according to the WHO classification of thyroid tumors (Hedinger 1988). The use of patient material and data was approved by the Ethics Committee of the Medical Faculty of the University of Bern.

Four thyroid carcinoma cell lines and one thyroid primary culture were also studied. Three follicular carcinoma cell lines established from a primary tumor (FTC133) and two metastases (FTC236, lymph node; FTC238, lung metastasis) from a single patient, were obtained from P E Goretzki, Dept of Surgery, University of Dusseldorf, Germany. A papillary carcinoma cell line, K1, was purchased from the European Collection of Cell Cultures (ECACC, Salisbury, UK). A thyroid cell culture (24HuSD) was derived from thyroid tissue from a Graves' disease patient.

\section{$R N A$ extraction}

Total RNA was extracted from tissue samples by the acid guanidinium thiocyanate-phenol-chloroform method (Chomczynski \& Sacchi 1987). Total RNA was prepared from cell lines using Trizol reagent (Gibco BRL, Bethesda, MD, USA). The quality of each preparation was checked by agarose gel electrophoresis of the RNA samples and of test RT-PCR products.

\section{Restriction-mediated differential display}

From each tissue sample, $50 \mu \mathrm{g}$ total RNA were reverse transcribed using cDNA primer CP28 V (5'-ACC TAC GTG CAG ATT TTT TTT TTT TTT TV-3' with $\mathrm{V}$ being a mixture of $\mathrm{A}, \mathrm{C}$ and $\mathrm{G}$, manufactured by Eurogentec, Seraing, Belgium). Double-stranded cDNAs were digested with $\mathrm{MboI}$ for $1 \mathrm{~h}$ at $37^{\circ} \mathrm{C}$ and ligated to linker ML2025 (prepared by hybridization of oligonucleotides ML20, 5'-TCA CAT GCT AAG TCT CGC GA-3' ${ }^{\prime}$, and LM25, 5'-GAT CTC GCG AGA CTT AGC ATG TGA C- $3^{\prime}$ ) overnight at $16{ }^{\circ} \mathrm{C}$. First round amplification was performed, using $1 / 20$ th of the ligation mix, in $1 \times$ PCR buffer containing $1.5 \mathrm{mM} \mathrm{MgCl}, 2 \mu \mathrm{M}$ dNTPs, $0 \cdot 4 \mu \mathrm{M}$ each of anchor primer CP28X $\left(5^{\prime}\right.$-ACC TAC GTG CAG ATT TTT TTT TTT TTT TX-3' $(\mathrm{X}=\mathrm{A}, \mathrm{C}$ or $\mathrm{G})$ ) and linker primer ML19Y $\left(5^{\prime}-\mathrm{TGC}\right.$ TAA GTC TCG CGA GAT CZ-3' (Z=A, C, G, or T)), and $1 \mathrm{U}$ AmpliTaq polymerase (Perkin-Elmer, Foster City, CA, USA). After 15 cycles $\left(20 \mathrm{~s}\right.$ at $94{ }^{\circ} \mathrm{C}, 30 \mathrm{~s}$ at $60{ }^{\circ} \mathrm{C}$, and $4 \mathrm{~min}$ at $72{ }^{\circ} \mathrm{C}$ ), reactions were supplemented with dNTPs to a final concentration of $200 \mu \mathrm{M}$ and amplified for another 10 cycles. This protocol will amplify only fragments at the $3^{\prime}$ end of the cDNA. Second round 


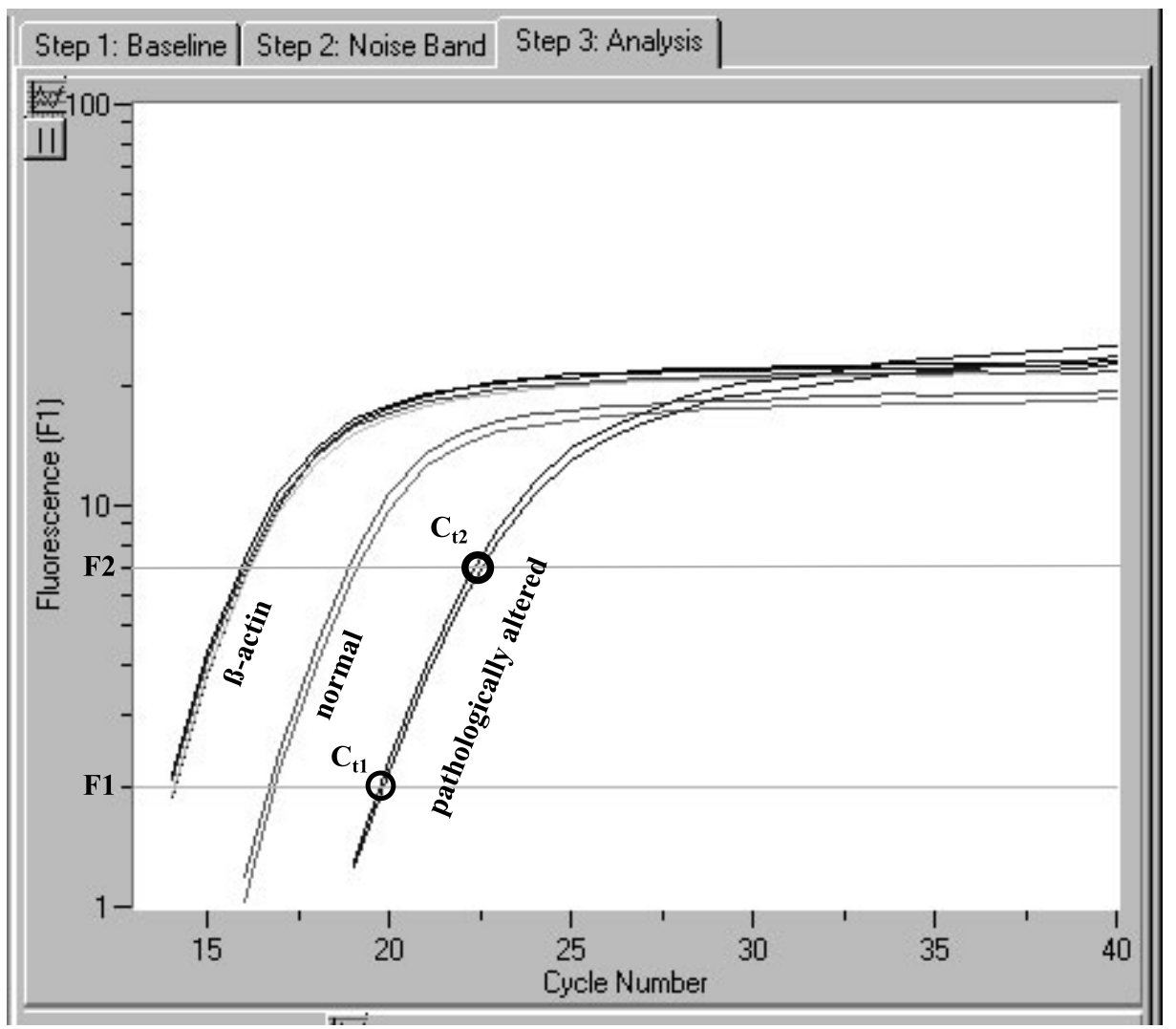

Figure 1 Screen shoot of a LightCycler run. Arbitrary relative fluorescence versus cycle number is shown. Normal and pathologically altered samples have been tested in duplicate, for Fc $\gamma$ BP and $\beta$-actin expression respectively. Cycle efficiency $E$ (which is the slope of the linear part of the graph) was determined using the formula $\log E=\log F_{2}-\log F_{1} / C_{t 2}-C_{t 1}$, where $F$ is the arbitrary relative fluorescence and $C_{t}$ is the cycle number at the crossing points of the slope with $F_{1}$ and $F_{2}$. Factors of

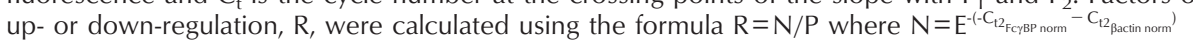

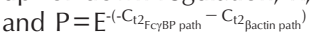

amplification was run for 20 cycles using $2 \mu \mathrm{l}$ of a 1:100 dilution of the first round product and second round primers CP28XX1 (5'-ACC TAC GTG CAG ATT TTT TTT TTT TTT TXX1-3' (X1=A, C, G, or T)) and Bio-ML18ZZ1 (5'-Biotin-GCT AAG TCT CGC GAG ATC ZZ1-3' (Z1=A, C, G, or T)). This step increases the resolution and sensitivity of the detection of the $3^{\prime}$-cDNA fragments. Each primer set allows the amplification and analysis of a defined subset of fragments. Reactions were analyzed on a $6 \%$ denaturing polyacrylamide gel on a GATC 1500 Direct Blotting Electrophoresis apparatus (Beck \& Pohl 1984) (GATC GmbH, Konstanz, Germany).

Electrophoresis took place for 3-4 hours with a constant power of $30 \mathrm{~W}$ applied. After a pre-run of $45 \mathrm{~min}$, the conveyor belt with a $40-\mathrm{cm}$ piece of Direct Blotting Membrane (GATC $\mathrm{GmbH}$ ) attached was started. Transport speed was $12 \mathrm{~cm} / \mathrm{h}$. After air-drying, the membrane was UV fixed $\left(10000 \mu \mathrm{J} / \mathrm{cm}^{2}\right)$ in a Stratalinker (Stratagene, La Jolla, CA, USA) and color detection was performed using a streptavidin-alkaline phosphatase conjugate (Sigma) and NBT/BCIP (Roche Molecular Biochemicals, Mannheim, Germany). Bands of interest were excised and stored in $50 \mu \mathrm{l} 10 \mathrm{mM}$ Tris $-\mathrm{HCl} / 1 \mathrm{mM}$ EDTA, pH $8 \cdot 0$, at $4{ }^{\circ} \mathrm{C}$. Reamplification was performed on the excised bands in a PCR mixture containing $0 \cdot 8 \mu \mathrm{M}$ each of the previously used second round primers, $1.5 \mathrm{mM}$ $\mathrm{MgCl}_{2}, 200 \mu \mathrm{M} \mathrm{dNTPs}$, and $1 \mathrm{U}$ AmpliTaq polymerase under the above cycling conditions, for 30 cycles. Reamplification products were gel-purified by a second round of direct blotting electrophoresis and band recovery. Purified fragments were sequenced using the cycle sequencing protocol on a 373 DNA sequencer (Perkin Elmer) using the primer $\mathrm{CP}_{28 X X_{1}}$.

\section{Fc $\gamma B P$ RT-PCR}

Two micrograms total RNA were reverse transcribed in a $20 \mu \mathrm{RT}$ reaction containing $50 \mathrm{mM}$ Tris $-\mathrm{HCl}(\mathrm{pH}$ 8.3), $75 \mathrm{mM} \mathrm{KCl}, 3 \mathrm{mM} \mathrm{MgCl}, 10 \mathrm{mM}$ dithiothreitol, $1 \mathrm{mM}$ 
Table 1 List of differentially expressed genes in papillary thyroid carcinomas. Some of these genes are part of other expression studies (data not shown)

\begin{tabular}{ll} 
& Accession number \\
\cline { 2 - 2 } Gene & \\
IgG Fc binding protein & (Fc $\gamma$ BP) \\
Alpha-B-crystallin & S45630 \\
Cadherin-16 & AF016272 \\
EST & AA962212 \\
Chromosome 7 sequence & AC006350 \\
Alpha 1-antitrypsin & X01683 \\
Lactadherin (BA46) & U58516 \\
FC-epsilon-receptor gamma chain & M33195 \\
Fibronectin & X02761 \\
Glycoprotein-39 & M80927 \\
Laminin-5 beta 3 chain & D37766 \\
EST & Al738984 \\
&
\end{tabular}

dNTPs, $1 \mu \mathrm{M}$ oligo $\mathrm{dT}_{15}$ primer (Roche Molecular Biochemicals), 20 U RNasin (Promega, Madison, WI, USA) and $25 \mathrm{U}$ M-MLV reverse transcriptase (Promega). PCR was performed with primers specific for IgG Fc binding protein $(\mathrm{Fc} \gamma \mathrm{BP})$ : Fc $\gamma \mathrm{BP}$ forward $\left(5^{\prime}-\mathrm{CTG}\right.$ AGT ACT TCC GCC AAT GC-3') and Fc $3^{\prime}$ BP reverse $\left(5^{\prime}-\mathrm{GAG}\right.$ TTT ACC GGC AAG TAT CG-3'). As an internal control, PCR was also performed with $\beta$-actin primers: $\beta$-actin forward $\left(5^{\prime}\right.$-CCT CGC CTT TGC CGA TCC$\left.3^{\prime}\right)$ and $\beta$-actin reverse $\left(5^{\prime}\right.$-GGA TCT TCA TGA GGT AGT CAG TC-3') (Raff et al. 1997). The RT reaction was diluted to $50 \mu \mathrm{l}$, and $2 \mu \mathrm{l}$ were used as template in a $25 \mu \mathrm{l}$ PCR containing $50 \mathrm{mM} \mathrm{KCl}, 10 \mathrm{mM}$ Tris- $\mathrm{HCl}$ $(\mathrm{pH} 9 \cdot 0), 1 \times$ Triton X-100, $1.5 \mathrm{mM} \mathrm{MgCl}_{2}, 0 \cdot 2 \mathrm{mM}$ dNTPs, $0 \cdot 4 \mu \mathrm{M}$ of each primer and $1.25 \mathrm{U}$ Taq polymerase (Promega). Cycling conditions were $1 \mathrm{~min}$ at $94^{\circ} \mathrm{C}$, $1 \mathrm{~min}$ at $55^{\circ} \mathrm{C}$, and $1 \mathrm{~min}$ at $72^{\circ} \mathrm{C}$ for 30 cycles. PCR products were visualized by ethidium bromide staining of agarose gels.

\section{Real-time quantitative PCR}

Two micrograms total RNA were reverse transcribed in a $20 \mu \mathrm{l}$ reaction as described above. Primers designed for real-time PCR were: $\beta$-actin forward, $5^{\prime}-\mathrm{CTG}$ CGT GTG GCT CCT GAG GAG CA-3'; $\beta$-actin reverse, 5'-CCA GTG TGA CGG CCA GAG GCG T-3'; Fc $\gamma$ BP forward, 5'-TAC CGC CAA TGA TCG GCC AT-3'; and Fc $\gamma B P$ reverse, 5'-GCC CTG GAG AGA CAG CTT-3'. Quantitative PCR was performed using the LightCycler DNA Master SYBR Green I mix (Roche Molecular Biochemicals), $4 \mathrm{mM} \mathrm{MgCl}$ and $10 \mathrm{pM}$ each of forward and reverse primers. Reactions were performed in triplicate. Amplification was performed in a LightCycler Thermocycler (Roche Molecular Biochemicals) and cycle parameters were $95{ }^{\circ} \mathrm{C}$ no hold, $59{ }^{\circ} \mathrm{C}$ for $6 \mathrm{~s}$, and $72{ }^{\circ} \mathrm{C}$ for $30 \mathrm{~s}$. For each sample, expression levels of

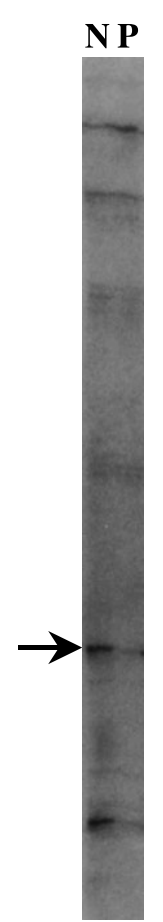

Figure 2 Restriction-mediated differential display membrane after electrophoresis on the Direct Blotting Electrophoresis system (GATC $\mathrm{GmbH}$ ) and colorimetric detection of biotinylated PCR products. $\mathrm{P}$, a papillary thyroid carcinoma sample and $\mathrm{N}$, a normal thyroid sample. The differentially expressed band indicated by the arrow is the Fc $\gamma B P$ fragment.

Fc $\gamma B P$ mRNA were calculated, relative to $\beta$-actin, from the semi-logarithmic graphs of relative fluorescence versus cycle number (Fig. 1).

Cycle efficiency E (which is the slope of the linear part of the graph) was determined using the formula $\log \mathrm{E}=\log$ $\mathrm{F}_{2}-\log \mathrm{F}_{1} / \mathrm{C}_{\mathrm{t} 2}-\mathrm{C}_{\mathrm{t} 1}$, where $\mathrm{F}$ is the arbitrary relative fluorescence and $\mathrm{C}_{\mathrm{t}}$ is the cycle number at the crossing points of the slope with $F_{1}$ and $F_{2}$. Factors of up- or down-regulation, $\mathrm{R}$, were calculated using the formula $\mathrm{R}=\mathrm{N} / \mathrm{P}$ where

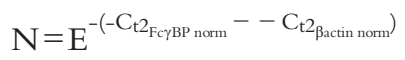

and

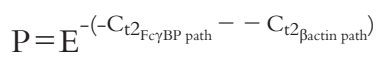

\section{Statistics}

Statistical analysis was carried out using the StatView package (Abacus concepts, Berkeley, CA, USA). A threesample comparison was performed for the ratio of Fc $\gamma B P$ mRNA expression levels using the Kruskal-Wallis test for non-parametric data. The ratios compared were those found in malignant thyroid tissue relative to normal 
A
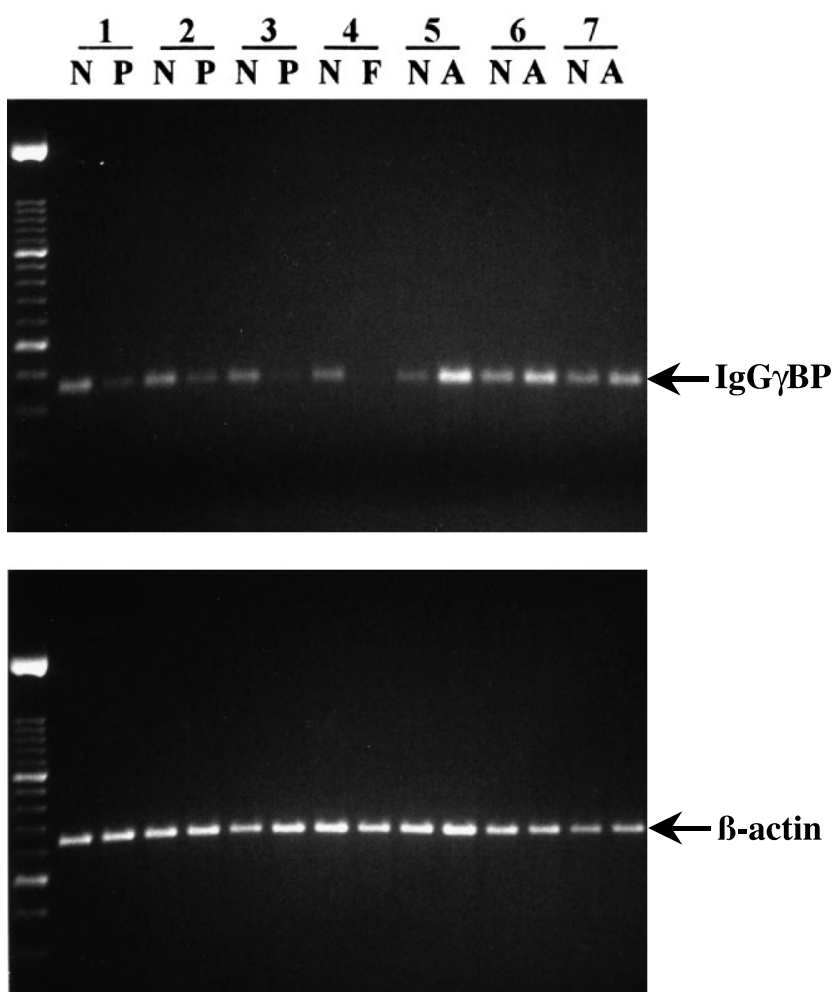

B

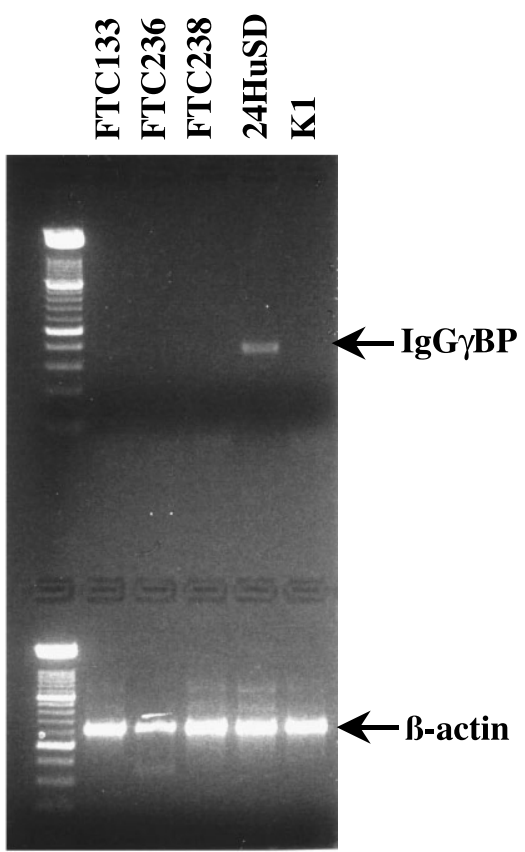

Figure 3 (A) Fc $\gamma$ BP and $\beta$-actin RT-PCR analysis of tissue samples from papillary carcinomas (P), follicular carcinomas (F), follicular adenomas (A), and normal thyroid tissues $(\mathrm{N})$. The RT was performed using $2 \mu \mathrm{g}$ total RNA with an oligo dT ${ }_{15}$ primer and PCRs were performed for 25 cycles with an annealing temperature of $60^{\circ} \mathrm{C}$ using primers specific for $\mathrm{Fc} \gamma \mathrm{BP}$ and $\beta$-actin. The molecular weight marker in lane 1 is a 100 bp ladder. (B) RT-PCR analysis of RNA from cell cultures. RT-PCR conditions were as described for (A). FTC133 was derived from a primary follicular carcinoma and FTC236 and FTC238 were derived from a lymph node and a lung metastasis of the same follicular carcinoma. 24HuSD is a primary culture of thyroid tissue from a Graves' disease patient and K1 is a papillary thyroid carcinoma cell line.

thyroid tissue, in Hurtle cell adenomas relative to normal thyroid tissue and in thyroid adenomas and hyperplasias relative to normal thyroid tissue. A $P$ value of less than $0 \cdot 05$ was considered significant.

\section{Results}

Differential display was performed using a modified technique, developed by A Fischer, named restrictionmediated differential display (RMDD) (Fischer 1995).

Initially, RMDD was performed with RNA from two thyroid papillary carcinomas and corresponding normal thyroid tissue from the same patients. Twelve cDNA fragments showing differential expression were purified and sequenced (Table 1). One of the cDNA fragments, approximately $175 \mathrm{bp}$ in size (indicated by an arrow in Fig. 2 ), the expression of which was reduced in the papillary thyroid carcinoma samples, showed 99\% homology to Fc $\gamma B P$ (Harada et al. 1997). This gene was selected for further analysis because its expression has not previously been described in thyroid tissue. Reduced expression of Fc $\gamma B P$ mRNA in the papillary carcinoma samples was confirmed by RT-PCR (Fig. 3A).

To obtain quantitative data on the expression of Fc $\gamma B P$ mRNA in thyroid carcinomas, thyroid adenomas, thyroid nodular hyperplasia and normal thyroid tissue, we performed real-time quantitative RT-PCR, which measures the incorporation of fluorescent SYBR green dye into newly synthesized double stranded DNA, after each round of elongation. Levels of $\mathrm{F} c \gamma \mathrm{BP}$ mRNA were normalized relative to $\beta$-actin mRNA, which was used as a control and internal standard. Table 2 shows the ratio of the relative expression of Fc $\gamma B P$ mRNA between pathologically altered and normal thyroid tissues. In all carcinoma samples tested from six papillary and three follicular cancers, levels of Fc $\gamma B P$ mRNA expression were lower than in the corresponding normal thyroid samples (ratio <1) (Table 2). In contrast, all six of the thyroid adenoma samples tested showed higher levels of Fc $\gamma B P$ mRNA than the corresponding normal tissue (ratio $>1$ ). In three of the four thyroid nodular hyperplasias 
Table 2 Expression of Fc $\gamma B P$ mRNA in normal and pathological tissue, normalized to the respective expression of $\beta$-actin mRNA and ratio of Fc $\gamma B P$ mRNA expression in benign and malignant thyroid nodules versus normal thyroid tissue, determined by quantitative real-time quantitative PCR

\begin{tabular}{|c|c|c|c|c|c|c|}
\hline & Age & Sex & Diagnosis & Normal & Pathological & $\begin{array}{l}\text { Ratio of } \\
\text { Fc } \gamma \text { BP }\end{array}$ \\
\hline \multicolumn{7}{|c|}{ Patient } \\
\hline 1 & 32 & f & PTC & $0 \cdot 071$ & 0.035 & 0.5 \\
\hline 2 & 21 & f & PTC & $0 \cdot 4$ & $0 \cdot 03$ & $0 \cdot 1$ \\
\hline 3 & 32 & f & PTC & $0 \cdot 19$ & 0.03 & $0 \cdot 2$ \\
\hline 4 & 64 & $f$ & PTC & $0 \cdot 4$ & 0.033 & $0 \cdot 1$ \\
\hline 5 & 34 & $\mathrm{f}$ & PTC & $0 \cdot 152$ & 0.079 & 0.5 \\
\hline 6 & 16 & $\mathrm{f}$ & PTC & $0 \cdot 32$ & $0 \cdot 082$ & $0 \cdot 3$ \\
\hline 7 & 47 & f & FTC & $0 \cdot 245$ & 0.032 & $0 \cdot 1$ \\
\hline 8 & 36 & $f$ & FTC & $0 \cdot 315$ & $0 \cdot 181$ & $0 \cdot 6$ \\
\hline 9 & 76 & $\mathrm{~m}$ & FTC & 0.0257 & $0 \cdot 0098$ & $0 \cdot 4$ \\
\hline 10 & 19 & f & $\mathrm{OA}$ & $0 \cdot 257$ & 0.09 & $0 \cdot 4$ \\
\hline 11 & 61 & $f$ & OA & $0 \cdot 215$ & 0.07 & $0 \cdot 3$ \\
\hline 12 & 26 & $f$ & OA & $0 \cdot 274$ & $0 \cdot 211$ & $0 \cdot 8$ \\
\hline 13 & 84 & $\mathrm{~m}$ & FA & 0.062 & $0 \cdot 204$ & $3 \cdot 3$ \\
\hline 14 & 58 & $f$ & FA & 0.0489 & 0.271 & $5 \cdot 5$ \\
\hline 15 & 69 & $\mathrm{~m}$ & FA & $0 \cdot 0025$ & 0.026 & $10 \cdot 4$ \\
\hline 16 & 60 & $\mathrm{~m}$ & FA & $0 \cdot 234$ & $0 \cdot 52$ & $2 \cdot 2$ \\
\hline 17 & 66 & $\mathrm{~m}$ & FA & $0 \cdot 0082$ & 0.03 & $3 \cdot 7$ \\
\hline 18 & 62 & $\mathrm{f}$ & FA & 0.425 & 0.622 & $1 \cdot 5$ \\
\hline 19 & 31 & $f$ & $\mathrm{NH}$ & $0 \cdot 263$ & $0 \cdot 257$ & $1 \cdot 0$ \\
\hline 20 & 50 & $\mathrm{f}$ & $\mathrm{NH}$ & $0 \cdot 244$ & 0.583 & $2 \cdot 4$ \\
\hline 21 & 71 & $f$ & $\mathrm{NH}$ & $0 \cdot 0191$ & $0 \cdot 236$ & $12 \cdot 4$ \\
\hline 22 & 73 & f & $\mathrm{NH}$ & $0 \cdot 316$ & $0 \cdot 712$ & $2 \cdot 3$ \\
\hline
\end{tabular}

PTC, papillary thyroid carcinoma; FTC, follicular thyroid carcinoma; OA, oxyphilic adenoma; FA, follicular adenoma; $\mathrm{NH}$, nodular hyperplasia.

tested, Fc $\gamma B P$ mRNA expression was also higher in the hyperplastic nodule than in the corresponding normal thyroid tissue (ratio $>1$ ). The fourth hyperplasia sample showed similar levels of $\mathrm{Fc} \gamma \mathrm{BP}$ mRNA in the hyperplastic nodule and the normal tissue (ratio=1). However, three Hurthle cell adenomas (oxyphilic adenomas) showed lower levels of Fc $\gamma B P$ mRNA expression than normal tissue $($ ratio $<1)$.

Fc $\gamma$ BP expression was also assessed quantitatively (data not shown) and semi-quantitatively in four thyroid carcinoma cell lines (a papillary carcinoma cell line (K1), 3 follicular carcinoma cell lines (FTC133, FTC236, and FTC238)), and a primary cell culture of thyroid tissue from a Graves' disease patient (24HuSD). Fc $\gamma B P$ mRNA expression was only detected in the 24HuSD Graves' disease primary cell culture (semi-quantitative results Fig. 3B).

Statistical analysis confirmed that the ratio of Fc $\gamma B P$ mRNA expression in malignant relative to normal thyroid tissue (mean $=0.311)$ and Hurthle cell adenomas (relative to normal tissue) $($ mean $=0.5)$ is significantly lower than in benign follicular adenomas and nodular hyperplasia (relative to normal tissue) $($ mean $=4 \cdot 47) \quad(P=0 \cdot 0003$, Kruskal-Wallis test).

\section{Discussion}

The purpose of this study was to identify genes that are differentially expressed in malignant and benign thyroid tumors. Such genes could be useful in the important distinction between the majority of thyroid nodules, which are benign, and the minority of thyroid nodules, which are malignant.

The Fc $\gamma \mathrm{BP}$ gene investigated in this study has potential as a genetic marker in thyroid cancer. In each of the malignant thyroid tumors tested the ratio of $\mathrm{Fc} \gamma \mathrm{BP}$ mRNA expression (relative to normal tissue) was less than one, whereas in all the thyroid adenomas and in three out of four of the hyperplastic nodules the ratio of Fc $\gamma B P$ expression was greater than one. Measurement of Fc $\gamma \mathrm{BP}$ mRNA expression in thyroid tumors and surrounding normal tissues would thus have enabled us to predict the benign or malignant nature of these thyroid nodules.

Oxyphilic (Hurthle cell) adenomas seem to be an exception to the above rule since - contrary to the findings in thyroid follicular adenomas - FcrBP mRNA expression in the oxyphilic adenoma samples tested was lower than in the surrounding normal thyroid tissue. This 
suggests a difference in the regulation of $\mathrm{Fc} \gamma \mathrm{BP}$ mRNA expression between thyroid oxyphilic and follicular adenomas.

Diagnosis of thyroid cancer usually involves ultrasoundguided fine-needle aspiration biopsy. Papillary carcinomas have distinctive cytological features, which are usually easily recognized in a fine-needle aspiration biopsy specimen. However, follicular carcinomas are often difficult to distinguish from follicular adenomas because they have a similar microscopic appearance (Fagin 1994). RT-PCR for a carcinoma-specific marker, from fineneedle aspiration biopsies, would therefore be an attractive alternative to cytological examination. Fine-needle aspiration biopsy RT-PCR for oncofetal fibronectin has already shown promising results for the identification of papillary carcinomas (Takano et al. 1997). If downregulation of $\mathrm{Fc} \gamma \mathrm{BP}$ expression is characteristic of all thyroid carcinomas, measurement of Fc $\gamma \mathrm{BP}$ mRNA expression (using RT-PCR) could have great potential as a diagnostic marker to distinguish between benign and malignant thyroid tumors, in particular between follicular adenomas and follicular carcinomas. The fact that Fc $\gamma B P$ mRNA expression seems to be down-regulated in Hurthle cell adenomas should not pose too great a problem, since Hurthle cell adenomas have quite distinct cytological characteristics (Hedinger 1988). It will be interesting to measure $\mathrm{Fc} \gamma \mathrm{BP}$ mRNA expression in Hurthle cell carcinomas to determine if regulation of Fc $\gamma B P$ expression differs between Hurthle cell adenomas and carcinomas.

The precise role of the product of the Fc $\gamma \mathrm{BP}$ gene, the expression of which was analyzed in this study, is as yet unclear. Fc $\gamma B$ P was first identified as an $\operatorname{IgG}$ Fc binding site in intestinal and colonic epithelia (Kobayashi et al. 1989). It binds monomeric and aggregated $\operatorname{IgG}$ but is immunologically distinct from already known $\operatorname{IgG} \mathrm{FC}_{\mathrm{C}}$ receptors (Kobayashi et al. 1989). It is produced by goblet cells in the colon and seems to be secreted into the bowel lumen with mucus, which suggests that it might be involved in immune protection and inflammation in the intestine. The role of $\mathrm{Fc} \gamma \mathrm{BP}$ in the thyroid is equally unclear. It might possibly also contribute to immune protection in the thyroid. Down-regulation of Fc $\gamma \mathrm{BP}$ expression in papillary and follicular carcinomas could potentially facilitate immune evasion and therefore play a role in thyroid carcinogenesis and the progression of thyroid cancer.

In summary, we report the identification of Fc $\gamma B P$ as a differentially expressed gene in thyroid papillary and follicular cancer. We found that Fc $\gamma B \mathrm{BP}$ is expressed in normal thyroid and, more significantly, it is downregulated in papillary and follicular thyroid carcinomas. Further studies are required to determine the function of $\mathrm{Fc} \gamma \mathrm{BP}$ in the thyroid and the feasibility of using Fc $\gamma \mathrm{BP}$ expression as a diagnostic marker or prognostic indicator for thyroid cancer.

\section{Acknowledgements}

We would like to thank Dr M Bedoucha (F Hoffmann-La Roche AG) for his technical support for the LightCycler and Dr M E Bürgi-Saville for her help and valuable advice while reviewing the manuscript.

\section{References}

Beck S \& Pohl FM 1984 DNA sequencing with direct blotting electrophoresis. EMBO Journal 3 2905-2909.

Chomczynski P \& Sacchi N 1987 Single-step method of RNA isolation by acid guanidinium thiocyanate-phenol-chloroform extraction. Analytical Biochemistry 162 156-159.

Ezzat S, Sarti DA, Cain DR \& Braunstein GD 1994 Thyroid incidentalomas. Prevalence by palpation and ultrasonography. Archives of Internal Medicine 154 1838-1840.

Fagin JA 1994 Molecular genetics of human thyroid neoplasms. Annual Review of Medicine 45 45-52.

Fischer A 1995 German patent application number: DE 19518 505·6. Fischer A, Saedler H \& Theissen G 1995 Restriction fragment length polymorphism-coupled domain-directed differential display: a highly efficient technique for expression analysis of multigene families. PNAS 92 5331-5335.

Harada N, Iijima S, Kobayashi K, Yoshida T, Brown W, Hibi T, Oshima A \& Morikawa M 1997 Human IgG Fc binding protein (FcgammaBP) in colonic epithelial cells exhibits mucin-like structure. Journal of Biological Chemistry 272 P15232-P15241.

Hedinger C 1988 Histological Typing of Thyroid Tumors, edn 2. Berlin: Springer.

Jhiang SM \& Mazzaferri EL 1994 The ret/PTC oncogene in papillary thyroid carcinoma. Journal of Laboratory and Clinical Medicine $\mathbf{1 2 3}$ 331-337.

Kato K 1996 RNA fingerprinting by molecular indexing. Nucleic Acids Research 24 394-395.

Kobayashi K, Blaser MJ \& Brown WR 1989 Identification of a unique IgG Fc binding site in human intestinal epithelium. Journal of Immunology 143 2567-2574.

Kroll T, Sarraf P, Pecciarini L, Chen C, Mueller E, Spiegelman B \& Fletcher J 2000 PAX8-PPARgamma1 fusion in oncogene human thyroid carcinoma. Science 289 P1357-P1360.

Lemoine NR, Mayall ES, Wyllie FS, Williams ED, Goyns M, Stringer B \& Wynford-Thomas D 1989 High frequency of ras oncogene activation in all stages of human thyroid tumorigenesis. Oncogene 4 159-164.

Matz M, Usman N, Shagin D, Bogdanova E \& Lukyanov S 1997 Ordered differential display: a simple method for systematic comparison of gene expression profiles. Nucleic Acids Research 25 2541-2542.

Prashar Y \& Weissman SM 1996 Analysis of differential gene expression by display of $3^{\prime}$ end restriction fragments of cDNAs. PNAS 93 659-663.

Raff T, van der Giet M, Endemann D, Wiederholt T \& Paul M 1997 Design and testing of beta-actin primers for RT-PCR that do not co-amplify processed pseudogenes. BioTechniques 23 456-460.

Ridgway E 1998 Medical treatment of benign thyroid nodules: have we defined a benefit? [editorial]. Annals of Internal Medicine $\mathbf{1 2 8}$ P403-P405.

Russo D, Arturi F, Pontecorvi A \& Filetti S 1999 Genetic analysis in fine-needle aspiration of the thyroid: a new tool for the clinic. Trends in Endocrinology and Metabolism 10 280-285.

Schlumberger MJ 1998 Papillary and follicular thyroid carcinoma. New England Journal of Medicine 338 297-306. 
Takano T, Matsuzuka F, Sumizaki H, Kuma K \& Amino N 1997 Rapid detection of specific messenger RNAs in thyroid carcinomas by reverse transcription-PCR with degenerate primers: specific expression of oncofetal fibronectin messenger RNA in papillary carcinoma. Cancer Research 57 P3792-P3797.

Takano T, Miyauchi A, Yokozawa T, Matsuzuka F, Liu G, Higashiyama T, Morita S, Kuma K \& Amino N 1998 Accurate and objective preoperative diagnosis of thyroid papillary carcinomas by reverse transcription-PCR detection of oncofetal fibronectin messenger RNA in fine-needle aspiration biopsies. Cancer Research 58 P4913-P4917.

Welsh J, Chada K, Dalal SS, Cheng R, Ralph D \& McClelland M 1992 Arbitrarily primed PCR fingerprinting of RNA. Nucleic Acids Research 20 4965-4970.

Received in final form 14 May 2002

Accepted 14 May 2002 